\title{
Music Education Training for Teachers
}

\section{Cristina Rolim Wolffenbüttel}

Music Department, State University of Rio Grande do Sul, Montenegro, Brazil

Email: aristina-wolffenbuttel@uergs.edu.br

How to cite this paper: Wolffenbüttel, C. R. (2019). Music Education Training for Teachers. Creative Education, 10, 2101-2110. https://doi.org/10.4236/ce.2019.1010152

Received: August 9, 2019

Accepted: October 8, 2019

Published: October 11, 2019

Copyright (c) 2019 by author(s) and Scientific Research Publishing Inc. This work is licensed under the Creative Commons Attribution International License (CC BY 4.0).

http://creativecommons.org/licenses/by/4.0/

\begin{abstract}
This article is the result of a set of continuing education actions for teachers of the Porto Alegre Municipal Teaching Network (RME-POA), which made possible the learning in music and the expanding of the existing knowledge. From the realization of the courses "Musical Education in Preschool", "Music Education in Elementary School" was observed its contribution to the pedagogical practices of the teachers, impelling an investigation to understand the impacts of these actions with the RME-POA. The methodology used included the qualitative approach, participant research, observations, and interviews. Content analysis was the technique for data analysis. As a result, the relevance of continuing education courses for teachers who know the pedagogical practices of their colleagues from a sharing of work developed in the course, felt renewed to work more and better their own practices.
\end{abstract}

\section{Keywords}

Music Education, Continuing Education, Preschool, Elementary School, Basic Education

\section{Introduction}

This article presents the results of the actions undertaken with teachers of the Municipal Education Network of Porto Alegre (RME-POA), from a partnership between the Municipal Education Secretariat of Porto Alegre (SMED-POA) and the State University of Rio Grande do Sul (UERGS). The focus of the actions was to contribute to the continued training of teachers who work in the Basic Education of RME-POA, enabling their participation in the activities of this program. It was also sought to contribute to the construction of planning and implementation of music projects in schools of this municipality. Thus, as a general objective, this project sought to expand the actions of insertion of music in the Basic Education of RME-POA.

It is worth highlighting that in the course of activities, due to a number of 
factors, among which can be mentioned political, economic and social reasons ${ }^{1}$, this project that initially presupposed the realization of extensionist actions of music education training for teachers, ended up absorbing, also, an investigative bias, which came to enrich it even more. In addition, the initial planning was based on the realization of meetings that aimed to discuss methodologies for teaching music in school, as well as possible forms of evaluation for this teaching. It is made clear that these topics were not stopped during the activities of the project. However, from the suggestions of the participating teachers, a work format was implemented based on the sharing of their experiences.

Thus, at each meeting, one or more teachers presented their teaching practices, projects and ways of working. This procedure proved to be extremely effective, because it came from the experiences and realities of each one, contributing to the collective knowledge. According to Hargreaves (1998), it is important that the working relationships between teachers are collaborative, spontaneous, voluntary and developmental, disseminated in time and space, and often unpredictable. Day (2001: p. 130) also explains that in these relations, "teachers use their discretion to initiate tasks or to respond selectively to external requirements". Therefore, and according to the author, it is important to note that when collaboration is understood as "an effective means for teacher development, it will impact on the quality of student learning opportunities and thus indirectly or directly on their motivation and development" (Day, 2001: p. 131).

\section{The Importance of Knowing the Works of the Teachers}

Despite the understanding of the importance of offering continuous training activities for teachers, according to Del Ben (2000), the systematic data on musical education practices of music teachers working in schools are still scarce. According to the author, little is yet known about what they think and what music teachers do in their teaching practices, as well as what their difficulties and challenges are in the school context. For Del Ben (2000), it is important to know in more depth how these teachers develop their educational-musical practices in school contexts. This could support the development of intervention projects and curricular and initial and continuing training policies that meet the needs, characteristics, limits and possibilities of both schools and teachers (Del Ben, 2000).

Based on this assumption, the courses conducted in partnership between SMED-POA and UERGS, denominated "Musical Education in Preschool" and "Musical Education in Elementary School" were developed with the objective of providing a more in-depth knowledge of the work of the teachers, in this case, teachers of RME-POA municipal preschools, and municipal elementary schools, and to meet the needs, limits, and possibilities of both schools and teachers.

${ }^{1}$ In the year 2017, in the City of Porto Alegre-Brazil, there was a series of civil service movements, which were based on claims related to their career. As a consequence, at various times, the activities of most public servants were paralyzed, including municipal teachers. 


\section{Music Teaching in Schools and Partnership with the University}

Regarding the importance of music teaching in schools, Del Ben \& Hentschke (2002) propose:

The teaching of music in schools, as a human and social practice, is constituted by the actions of its participants. In this sense, the transformation of pedagogical-musical practice in schools can only happen through the concrete and daily actions of its participants. This transformation necessarily involves teachers with their own conceptions and actions, their frame of reference, their personal beliefs and experiences and even their inconsistencies, contradictions or unquestionable truths (Del Ben \& Hentschke, 2002: p. 55).

This refers to the need for approachment and partnership, on the one hand, between researchers and teacher trainers and, on the other hand, music teachers who already work in schools, suggesting paths for the continued training of these professionals. The partnership proposal reinforces the view that scientific knowledge alone is not capable of transforming existing practices. They can enhance teachers' reflection on their own conceptions and actions, collaborating so that the existing practice can be resized and transformed by the teachers themselves. In this perspective, UERGS, along with the Municipal Secretariat of Education of Porto Alegre (Rio Grande do Sul-Brazil), has built extension projects for teachers in various areas, including for music teachers.

Considering this context and, in view of the existence of music teachers working in the municipality of Porto Alegre (Rio Grande do Sul-Brazil), in addition to the importance of the continued training of these professionals, some questions arose during the course of the continued training with them: How was the work sharing among the teachers of RME-POA? How did the teachers feel watching the pedagogical-musical works of their colleagues at RME-POA? Has participation in the course affected teachers' pedagogical practices in any way? How was the professional relationship between teachers of RME-POA, after the courses? In general, what was it like to participate in the Musical Education Course in Preschool and Elementary School? What do teachers think about continuing training courses?

Starting from these questions, this research aimed to investigate the realization of extension actions, with a focus on continued training, along with music teachers and professionals who develop musical activities in schools of RME-POA.

\section{The Methodological Paths Followed}

This project, which was set up as a set of extension actions which also resulted in a research, and had its own methodology for each type of action performed.

The extension methodology took place through two courses, called Musical Education Course in Preschool and Elementary School? They occurred in the period from June to October, 2017, with a periodicity of once a month. This way, in the month both courses occurred, on different days, being one meeting fo- 
cused on Preschool and another in Elementary school.

The initial planning was guided by the realization of meetings that aimed to discuss the methodologies for teaching music in schools, as well as the evaluation possibilities for this teaching. As previously stated, the courses did not fail to bring these topics during the activities of the project. However, from the suggestions of the participating teachers, a work format based on sharing experiences was implemented. Thus, at each meeting, one or more teachers presented their teaching practices to their colleagues. This procedure proved to be extremely effective because it came from the experiences and realities of each one contributing to the collective knowledge.

The methodology used to conduct the research was based on the qualitative approach, the participant research as a method, and the performance of observations and interviews as techniques for data collection. The technique for data analysis was content analysis.

The qualitative approach, according to Bogdan \& Biklen (1994):

It is not done in order to answer previous questions or to test hypotheses, they essentially privilege the understanding of behaviors from the perspective of the subjects of the investigation. External causes are considered of secondary importance. They normally collect data based on in-depth contact with individuals in their natural ecological contexts (Bogdan \& Biklen, 1994: p. 16).

The participating research, according to Gil (2007), is based on the "interaction between the researcher and the research object", which characterized this research because the researchers participated in the courses "Musical Education in Preschool" and "Musical Education in Elementary School".

For data collection, observations were made during the course, unstructured interviews that occurred from informal conversations with the participating teachers, in addition to a questionnaire prepared and sent via Whatsapp to teachers. Observations, interviews, and questionnaires were organized constituting specific notebooks for data analysis. After, all this material was organized in a Categorization Notebook uniting the data of the three notebooks.

Finally, for data analysis, content analysis was used, which is characterized as a set of document exploration techniques that seeks to identify the main concepts or the main themes addressed in a given text. According to Moraes (1999):

Content analysis constitutes a research methodology used to describe and interpret the content of the entire class of documents and texts. This analysis, leading to systematic, qualitative or quantitative descriptions, helps to reinterpret messages and achieve an understanding of their meanings at a level that goes beyond a common reading (Moraes, 1999: p. 8).

\section{Reflective Teacher and the Principles of Musical Education as Theoretical Fundamentals}

The theoretical foundations of this research are structured in the concepts of reflective teacher and in the principles of Musical Education. 


\subsection{Reflective Teacher}

The reflective teacher's paradigm used in this research focused on the thoughts of Schön $(2000,1995,1987)$. The author is opposed to the paradigm of technical rationality, generally applicable in educational institutions. Schön's initial work was directed to the formation of architects, designers and engineers, and the great repercussion of his ideas founded, later, other theoretical formative models of teachers who also defend the need to transcend technical rationality.

For Schön, reflection on the action is in direct relation to the present action. The reflection on the action consists of a retrospective mental reconstruction of the action to try to analyze it, constituting a natural act with a new perception of the action. The reflection on the action happens when the teacher reconstructs the action mentally to analyze retrospectively, and a later look at the action performed helps the teacher to understand what happened during the action and how the unforeseen events occurred were solved.

There is unanimity about the need to value the teacher, his process of professionalization and his knowledge. In this sense, the model of the reflective teacher proposes the appreciation of teaching practice based on the paradigm of practical rationality, that is, a teaching activity that is based on the production of knowledge for ethical and social purposes. The teaching activity, in this perspective, is based on the epistemology of practice knowledge in action and the reflection generated in and from practice reflection in action and reflection on action, as suggested by Schön.

Schön $(1987,2000)$ characterizes the "knowledge-in-action" as a "knowing-inaction". Knowledge is reflected at the same time as the action characterizes what Schön calls reflection-in-action. It is a reflection within the "present -of-action", which is conscious and which may or may not be explicit. For Schön (1987, 2000: p. 28) reflection-in-action has "a critical function" that questions "the structure of assumptions of the act of knowing-in-action" Schön (1987, 2000: p. $30)$.

Schön (1995) defends the need to train reflective practices in the sense of conscious and creative intervention in his teaching practice, this means autonomous professionals able to define their own decisions in relation to their daily situations. The reflective teacher, therefore, is a researcher of his or her practice and deserves to be understood as a producer of knowledge.

The dynamic technical training and the practical-reflective training, from the discussion of Schön, is current and has been resized to meet the demands of the professionalization of the teacher. In this dialogue, the questions about the reflection on the practice become more focused on the formative discourses being the main axis of the construction, articulation, mobilization and transformation of the teaching knowledge.

\subsection{Principles of Musical Education}

Swanwick (2003) points out three principles of Musical Education, which are to 
consider music as a discourse, to consider students' musical discourse, and to have fluency from beginning to end in the process of musical education.

For Swanwick (2003: p. 18) "music is a form of speech as old as the human race" and is directly linked to the relationship of continuity and fluency of sounds. For the author, the experience of the musical event can be compared to a metaphorical experience of speech. Swanwick explains that listening to music analytically is not the best option to experience its fluent and continuous form. According to him, "listening to sounds like music requires us to give up paying attention to isolated sounds and to experience instead of an illusion of movement, a sense of weight, space, time and fluency" (Swanwick, 2003: p. 30).

According to Swanwick (2003), musical conversation, by definition, cannot be a monologue. Therefore, each student brings with him a mastery of musical understanding. They are already familiar with music, although they have not subjected it to analysis, which would be the role of musical education. It is important to be attentive and aware of the autonomy of students. Your curiosity is not awakened by music history lessons, simply, or by dictating what is important to be heard. There needs to be some room for choice, for decision-making, for personal exploitation. Respect for musical discourse and individual differences of students help in the curriculum organization. Thus, the integration of musical experiences, including composition, improvisation, performance and appreciation allows students to excel in different ways.

In the third principle pointed out by Swanwick (2003), having fluency from beginning to end, the author starts from the fact that music is a form of speech, and compares his learning to the acquisition of language, noting that they both have non-identical specificities. Swanwick (2003) explains that the acquisition of the mother tongue involves the hearing and oral experience with other people who speak this language and proposes this way of analysis in relation to the teaching and musical learning. In this sense, people initially learn to speak and listen, and then write. The same is proposed in relation to musical learning. The sequence proposed by Swanwick (2003: p. 69) is "listen, articulate, then read and write". Musical fluency, therefore, precedes reading and musical writing.

\section{Results and Data Analysis}

After the data collection, they were organized into two categories of analysis, namely: sharing the work among music teachers and the importance of meeting music teachers.

\subsection{Sharing the Work among Music Teachers}

The category of analysis sharing the works among music teachers pointed out the importance that teachers delegate to the knowledge around the work of colleagues. In general, teachers understand that by having the opportunity to share their work as well as to know the work done by colleagues, they have their own performance enriched. In this regard, one of the participating teachers made a 
statement:

I very much enjoyed sharing my work with colleagues because there is a very rich exchange of experiences. The work was carried out in a reality different from that of the colleagues, therefore it contributes to their work and their views contribute to expand my view on the group researched and the work undertaken at the school (Interviews Book).

Schön (1995) explains that reflection in action happens when teachers mentally construct their actions, analyzing them retrospectively. In addition, the possibility of further analysis of the actions performed allows teachers to understand what happened during the actions and resolutions of unforeseen events. In this sense, by sharing her work with the teachers during the course, the teacher who provided the testimony previously presented, in addition to this act of sharing the work, also reflected on her action, this reflection enriched by the comments and suggestions of the other colleagues of the courses.

A positive highlight in relation to the sharing of the work was also voiced by other teachers who explained to be "always good to share the work being done with those who understand the subject", and that the "moments of sharing are always enriching", because our colleagues always make suggestions and comments pertinent to the growth of work" (Interviews Book).

The comments on the specificity of the musical work refer to the concepts recommended by Swanwick (2003). The author proposes three principles of Musical Education, which are to consider music as a discourse, to consider the musical discourse of the students, and to have fluency from the beginning to the end of this pedagogical-musical process. Thus, when they pointed out the relevance of sharing knowledge regarding music teaching work and, mainly, of this practice being carried out with colleagues in the field, the teachers did so with the primacy of the principles pointed out by Swanwick (2003). Technical and pedagogical-musical analysis involving the three principles would not be possible if the teachers did not know the musical language. The three principles have, therefore, been taken into account.

Other notes of teachers expressed in interviews and questionnaires related to the importance of knowing the work of colleagues. According to the testimony of one of the teachers:

Watching the work done by colleagues was wonderful! Enriching in different ways because it takes you out of your comfort and makes you want to work with more materials and with more musical options, which are always extensive and differentiated from teacher to teacher and from class to class. All of the speeches helped for the planning and replanning of my work, expanding the scope of music in the experiences and pedagogical proposals applied to the students (Interviews Book).

For the teacher, knowing the work of colleagues made her rethink her own conceptions and pedagogical-musical actions. In this regard, Schön (1995) defends the need for opportunistic reflective moments of teachers, considering conscious and creative interventions in teaching practices. The courses carried 
out allowed these interventions. According to the reports of the participating teachers, it was possible to see that the sharing of their experiences influenced the creation of new practices. Thus, according to their statements, "listen to the reports of colleagues always gives us new ideas and assists in the organization and planning of the activities" (Interviews Book). Or, still, according to another teacher, it was possible to use in their own practices "two accounts to create the year-end classes" (Interviews Book).

\subsection{The Importance of Meetings Music Teachers}

In the perspective of the meetings with music teachers, characterized by the courses of Musical Education, it was observed the great relevance of its organization and effectiveness, especially given that they were directed to music teachers, or teachers with musical knowledge. This direction allowed the discussions to focus on specific issues, which these professionals are aware of. It is not excluded, here, the relevance of conducting training in Music and Musical Education with professionals from other areas, not least because this is a great commitment in the process of insertion of music in schools, with which is communized at the present time. However, there are situations where specificity should be addressed. And, it is understood, this was developed in these courses, which allowed to be treated the principles of Musical Education (2003), in its specificity, in a reflective perspective (Schön, 1987, 1995, 2000). In this regard, one of the participating teachers declared:

I could observe that different musical propositions are very welcome in preschool, and that I can work them freely with the support of the school team. I very much enjoyed getting to know and meeting colleagues sharing their work, especially the difficulties, and finding ways to build knowledge and school music practice. In this sense, I took advantage of all the moments of conversation, and breaks, to get to know and share experiences with colleagues (Interviews Book).

In addition to the aspect concerning the importance of holding the meetings, the teachers revealed that this accomplishment meets the work, in the sense of a pedagogical resistance to the difficulties that many have felt in their careers, whether it is the lack of materials for the proper development of teaching work or the lack of systematic meetings between colleagues in the field, except for the courses that were offered and which are analyzed in this research. In this regard, one of the teachers interviewed stated:

I would like to see more about the challenges dealt with than the achievements because achievements are special and important for everyone, especially for the area. But the challenges are barely spoken of and we have no one to turn to on the school system. We should assist each other in musical work and build forms of work and materials together (Interviews Book).

The teacher's request reveals the difficulties that education networks and education, in general, have gone through. The impossibility of holding meetings between teachers, or even the complete absence thereof, result in increasingly solitary work, which does not allow neither for collective reflection (Schön, 1987, 
1995, 2000) on education, nor Music Education (Swanwick, 2003). The reunions, the meetings, or even the courses such as those that were opportunized to the teachers, cause it to grow individually and collectively, or, as one of the teachers declared, "are indispensable for good work as a municipal public network" (Interviews Book).

\section{Conclusion}

From the courses "Musical Education in Preschool", "Musical Education in Elementary School" was inferred that their format, which was characterized by the sharing of the works of colleagues from the RME-POA, was extremely important to the teachers who participated. Through a questionnaire prepared via WhatsApp with questions about how the course occurred, it was possible to collect some answers from the questions: How was the sharing of work among teachers of RME-POA? How did the teachers feel watching the pedagogical-musical works of their colleagues at RME-POA? Has participation in the course affected teachers' pedagogical practices in any way? How was the professional relationship among teachers of RME-POA from the courses? In general, what was it like to participate in the Musical Education Course in Preschool and Elementary School? What do teachers think about continuing training courses?

These issues led to very interesting conclusions. All those who responded, in general, concluded that sharing their work, as well as watching the work of their colleagues was a very important exchange of experiences because each work was done in a context. Therefore, this contributed to the expansion of the perception of the work of each teacher. It is understood that this exchange of knowledge, made possible by the participation in the courses, broadened the reflections and investigations of teachers about their actions, which is extremely important for the evolution in their pedagogical practices.

It was also noticed that the courses provided new musical proposals, in addition to an incentive for the development of works involving the partnership with other teachers, as well as the community.

The courses ended up becoming spaces where the teachers of the RME-POA could meet, get to know each other, and unite, especially in times of difficulties when it comes to political issues, economic, and social by which the city of Porto Alegre went through on the occasion. In this sense, everyone felt united to continue to work with greater efficiency, will, and dedication.

Therefore, generally speaking, and from the responses of the teachers of the RME-POA, the need for continuing training courses is clear because they are still scarce and everyone feels they should happen more often, due to their importance for the teaching career.

When completing the courses mentioned and, mainly, when conducting this research, the importance of continued training with teachers was observed. It is expected that this research, when presenting the data on the practices regarding the partnership between the university (UERGS) and the education system (SMED-POA) and to analyze them, can contribute to the growth of the elabora- 
tion of proposals of the same nature, thus contributing to the development of Musical Education.

\section{Conflicts of Interest}

The authors declare no conflicts of interest regarding the publication of this paper.

\section{References}

Bogdan, R. C., \& Biklen, S. K. (1994). Investigação qualitativa em educação: Uma introdução à teoria e aos métodos. Porto: Porto Editora.

Day, C. (2001). Desenvolvimento profissional de professores. Os desafios da aprendizagem permanente. Porto: Porto Editora.

Del Ben, L. (2000). Ouvir-ver música: Novos modos de vivenciar e falar sobre música. In J. Souza (Ed.), Música, cotidiano e educação (pp. 91-104). Porto Alegre: Programa de Pós-Graduação do Instituto de Artes da UFRGS.

Del Ben, L., \& Hentschke, L. (2002). Educação musical escolar: Uma investigação a partir das concepções e ações de três professoras de música. Revista da ABEM, Porto Alegre, 7, 49-57.

Gil, A. C. (2007). Como elaborar projetos de pesquisa. São Paulo: Atlas.

Hargreaves, A. (1998). Os professores em tempo de mudança: O trabalho e a cultura dos professores na idade pós-moderna. Lisboa: McGraw-Hill.

Moraes, R. (1999). Análise de conteúdo (pp. 7-31). Educação, Porto Alegre: Pontifícia Universidade Católica do Rio Grande do Sul, ano XXII, n. 37, março.

Schön, D. A. (2000). Educando o profissional reflexivo: Um novo design para o ensino e a aprendizagem. Trad: Roberto Cataldo Costa. Porto Alegre: Artes Médicas Sul.

Schön, D. A. (1995). Formar professores como profissionais reflexivos. In N. António (Ed.), Os professores e a sua formação (2nd Edition, pp. 77-91). Lisboa: Publicações Dom Quixote.

Schön, D. A. (1987). Educating the Reflective Practitioner: Toward a New Design for Teaching and Learning in the Professions. San Francisco, CA: Jossey-Bass Inc.

Swanwick, K. (2003). Ensinando música musicalmente. São Paulo: Moderna. 